A
3 days post ART initiation
(pre-CD8)

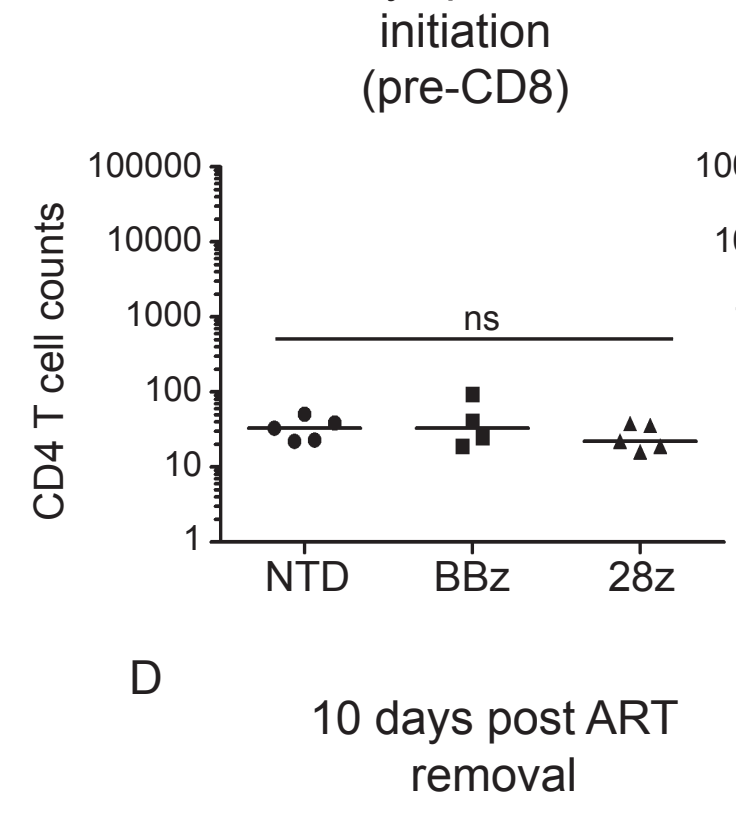

D

10 days post ART removal
B

18 days post ART removal

C

Endpoint
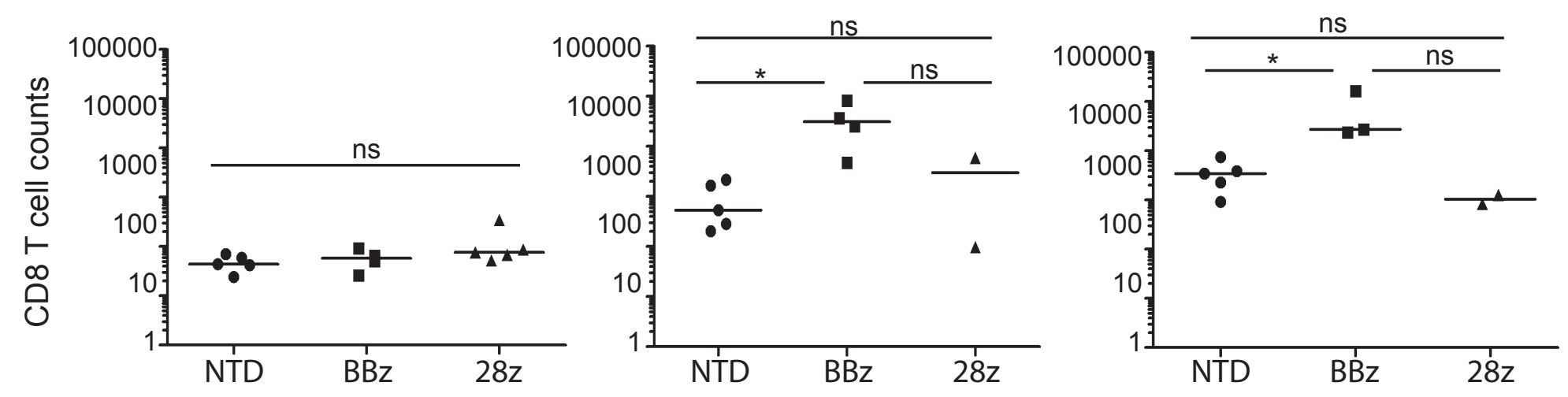

G

\begin{tabular}{|c|c|c|c|c|c|c|}
\hline CD4 T cell counts & $\begin{array}{c}\text { NTD } \\
\text { Mock }\end{array}$ & $\begin{array}{c}\text { NTD } \\
\text { HIV }\end{array}$ & $\begin{array}{c}\text { BBz } \\
\text { Mock }\end{array}$ & $\begin{array}{c}\text { BBz } \\
\text { HIV }\end{array}$ & $\begin{array}{c}28 z \\
\text { Mock }\end{array}$ & $\begin{array}{c}28 z \\
\text { HIV }\end{array}$ \\
\hline 4 days post ART initiation & 33 & 37 & 25 & 31 & 22 & 37 \\
\hline 10 days post ART removal & 395 & 44 & 160 & 223 & 331 & 238 \\
\hline 18 days post ART removal & 2,167 & 501 & 5,499 & 6,078 & 11,590 & 804 \\
\hline Endpoint & 12,621 & 199 & 5,553 & 4,413 & 8,326 & 3,322 \\
\hline
\end{tabular}

\title{
Leibman et al.
}

